\title{
Lead identification for the K-Ras protein: virtual screening and combinatorial fragment-based approaches [Corrigendum]
}

Pathan AAK, Panthi B, Khan Z, et al. OncoTargets and

Therapy. 2016;9:2575-2584.

On page 2582, panel A, B, C of Figure 5 had typographical and color issues. The correct images are as follows:
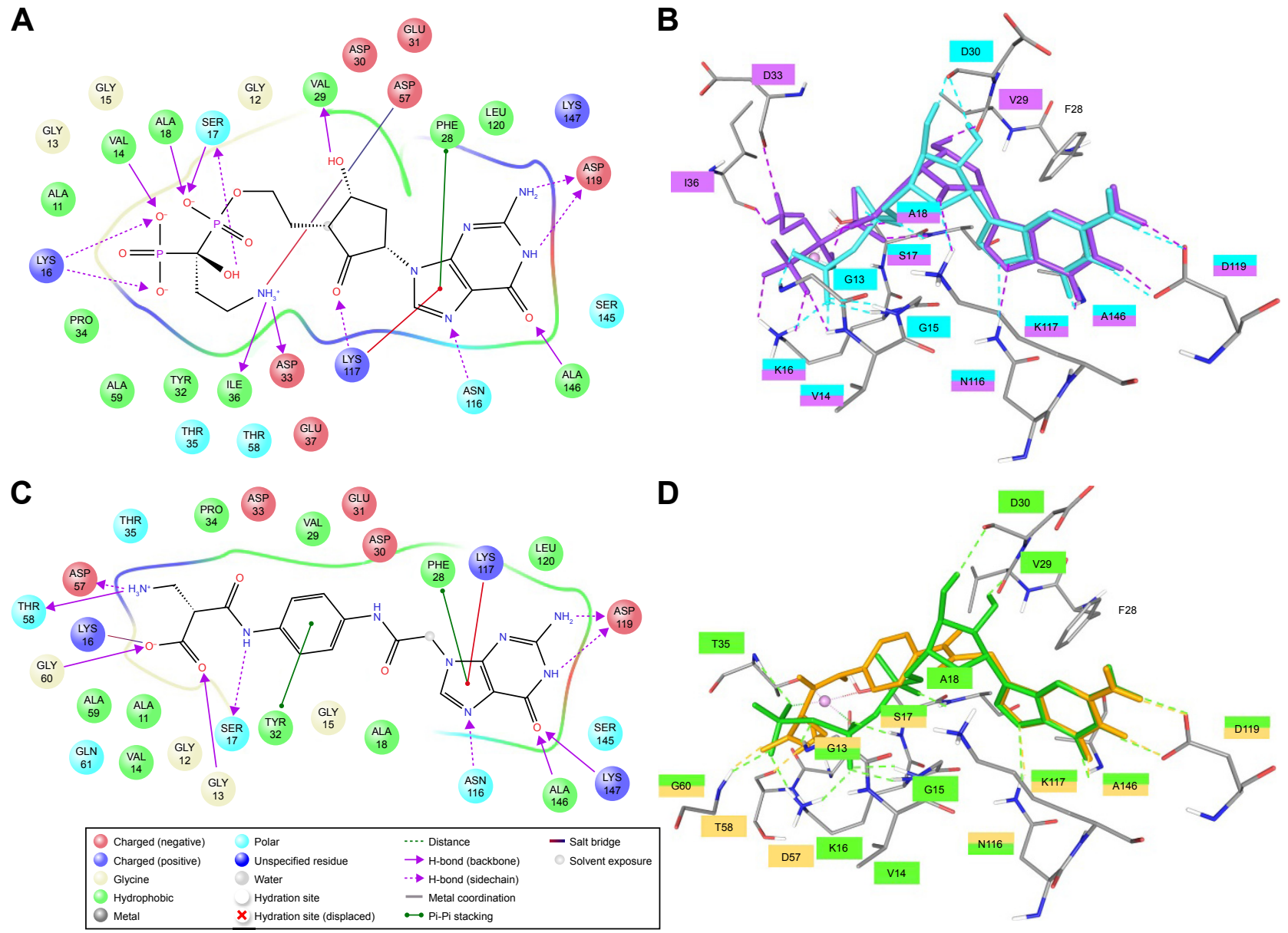

OncoTargets and Therapy

\section{Publish your work in this journal}

OncoTargets and Therapy is an international, peer-reviewed, open access journal focusing on the pathological basis of all cancers, potential targets for therapy and treatment protocols employed to improve the management of cancer patients. The journal also focuses on the impact of management programs and new therapeutic agents and protocols on patient perspectives such as quality of life, adherence and satisfaction. The manuscript management system is completely online and includes a very quick and fair peer-review system, which is all easy to use. Visit http://www.dovepress.com/testimonials.php to read real quotes from published authors. 